\title{
Suggesting The NOS Flow Map for an Instruction of Nature of Science
}

\author{
Oh, Jun-Young \\ (Hanyang University)
}

\section{과학의 본성 교육을 위한 NOS Flow Map 제안}

\section{오준영}

(한양대학교)

\begin{abstract}
국문초록
이 연구의 목적은 인지적 전략인, 갈등도 $(\mathrm{Oh}, 2011)$ 를 기반으로 학생들이 명시적으로 과학의 본성 (NOS)의 교육을 돕기 위하여 과학의 본성요소뿐만 아니라 과학의 역사를 담은 NOS Flow Map을 개발 제안하는 것이다. 예비적으로 과학의 본성의 교육을 위해 제안한 NOS Flow Map을 사용에 대한 이해를 탐색하기 위하여, 자신들의 NOS 이해를 강화하기 위해 우리가 제안한 NOS Flow Map의 유용성에 대한 예비 초등교사들의 인식를 조사하였다. 과학의 본성에 대한 중요한 관점들은 Kuhn의 과학철학과 역사 가 아주 잘 일치된다. 즉 Kuhn의 과학혁명의 예로 가장 중요한 Copernicus의 혁명과정이 과학의 본성 중요한 요소들과 잘 일치됨을 보여준다. 따라서 이 연구에서 인지갈등을 통한 NOS 흐름도는 과학의 소양교육을 강화하는데 명시적이고 반성적인 도구이며 유망한 방법이라고 조심스럽게 제안한다.

주요어 : 과학의 역사, 과학의 본성, 인지전략, Kuhn의 철학, Copernicus의 혁명, 갈등도
\end{abstract}

\section{Introduction}

According to Matthews (1992; 1994; 2004), until the 1980s, the philosophy of science was practically absent from both science teaching programs and science teacher education. Instead, there was an implicit acceptance of untested conceptions of the nature of science.

In regard to pupils understanding the nature of science, many researches identify several advantages resulting from the historical approach (Duschl, 1990; Solomon et al., 1992; Irwin, 2000). Moreover, this review indicated that an explicit approach that utilizes elements from history and philosophy of science might be more effective than an implicit approach in enhancing science teachers' NOS views (Abd-El-Khalick, \& Lederman, 2000b). As an instructional intervention to promote both NOS and SCK, the history of science
(HOS) was utilized in this study. Considerable theoretical work has argued that the history of science (HOS) may serve as a productive tool for science learning (Jenkins, 1994; Matthews, 1994; Monk \& Osborne, 1997). Likewise, numerous empirical studies have explored the efficacy of using HOS as an instructional strategy for enhancing NOS understanding in various contexts (Abd-El-Khalick \& Lederman, 2000b; Dass, 2005; Irwin, 2000; Lin \& Chen, 2002). Additionally, Jenkins (1994) argued that HOS provides rich contexts for scientific development and insight into NOS.

The purpose of this study is to suggest the Flow Map of History of Science (HOS) instruction on students learning of Nature of Science (NOS) through cognitive strategy, in order to enhance their overall scientific literacy through explicitness and reflective- 
ness. Thus in this study we will consider why the nature of science has reached the philosophy of Kuhn, and will identify the stage that Historical case of Science can take the key elements of the nature of science, using concrete examples of Copernicus' Revolution, Galileo's explanations of Sunspot, and the history of Atomic models.

According to Buaraphan (2012, p.353), science teachers are, therefore, responsible for helping students attain an adequate understanding of NOS. To do so, science teachers themselves must first possess an adequate understanding of NOS. However, many studies have revealed that the conceptions of NOS held by science teachers are inadequate, incoherent, and fluid (Abd-El-Khalick \& BouJaoude, 1997). Moreover, science teachers often teach NOS implicitly and expect NOS to result as a byproduct of the inquiry process, though the literature suggests teaching NOS in an explicitreflective manner (Abd-El-Khalick \& Lederman, 2000a; Akerson et al., 2006; Bartholomew et al., 2004; Schwartz \& Lederman, 2002).

Kuhn propagate Piaget's 'the variation of cognitive structure' thesis into historians and philosophers of science, based on "Part of what I know about how to ask questions of dead scientists has been learned by examining Piaget's interrogations of living children" (Kuhn, 1977. p.21). Kuhn's first discussion of the cognitive structures and pedagogical conditions for the learning of scientific knowledge was involved in his "The Essential Tension (Kuhn, 1959)". Kuhn's first discussion of the cognitive structures and learning conditions for the learning of scientific knowledge was involved in his "The Essential Tension (Kuhn, 1959)". It was important components of the establishment of a paradigm that leaning, cognitive apprenticeships, and transmission of basic conceptions and methodologies were.

The conflict map (Tsai \& Chang, 2005; Oh, 2011) which is included with cognitive strategies, provided a useful framework, including a series of events, phenomena, and concepts, for students to engage in deeper exploration and discussion by helping them to re-conceptualize or make more connections between existing experiences or knowledge and new conceptions. Thus, we use this conflict map, because they could construct better representations for the target scientific conceptions.

The purpose of this study is to suggest a NOS Flow Map of History of Science (HOS) instruction for student learning of the Nature of Science (NOS) through a Cognitive Strategy, a Conflict Map (Oh, 2011).

First, a NOS Flow Map through the "new" Philosophy and History of science for Nature of Science (NOS)?

Second, the Instruction sequence of NOS Flow Map through Cognitive Strategy for the Nature of Science (NOS)?

Third, Historical Case Studies and a cognitive learning outcome for a NOS flow map?

Fourth, Preservice Elementary Teachers' views about using NOS Flow Maps through a Conflict Map?

\section{The NOS Flow Map through the new Philosophy and History of Science for Nature of Science (NOS)}

\section{The Nature of Science based on Kuhn's philosophy of Science.}

According to Matthews (2004), "despite realist views being robustly asserted by prominent philosophers of science, many science educators, for instance, believed that "constructivist views $\cdots$ hold sway among current philosophers of science" (Benson, 1989, p. 342)." However It is valuable to introduce students at the basic level to some of the ideas developed by Kuhn. In particular, recently we find that students benefit by considering the idea that different Kuhnian paradigms or Lakatosian research programs compete with each other, and that they can easily understand some of the ways in which theoretical commitments and social issues can influence the development of science (Oh, 2011). Philosophical debate about realism (Eflin, Glennan, \& Reisch, 1999) and strong social constructivism (Matthews, 1994) should be avoided. The middle of 
the road approach we offer here seems to be suggested by some of the NOS tenets given in the American Association for the Advancement of Science reports (AAAS, 1993) According to Cleminson (1990), new direction could be given to curriculum planning by basing it upon some of the common threads that emerge from the "new" philosophy of science. Thus the following assumptions could be used at a foundation as follows:

1. Scientific Knowledge is tentative and should never be equated with truth. It has only temporary status.

2. Observation alone cannot give rise to scientific knowledge in a simple inductivist manner. We view the world through theoretical lenses built up from prior knowledge. There can be no sharp definition between observation and inference.

3. New knowledge in science is produced by creative acts of the imagination allied with the methods of scientific inquiry. As such science is a personal and immensely human activity.

4. Scientists study of which they are a part, not a world from which they are apart

(Clemison, 1990, pp. 437-438)

Given the parallel between the process of theory development by Kuhn and new philosophy of science, it is agreed that the Kuhn's philosophy may serve as a productive tool for science learning. The portrayal of science as impersonal and unproblematic subject of study must be discarded. The image of the scientist as a rather eccentric man living a world apart from the one in which the rest of the population live has led to disenchantment with science lessons preferred the humanities to the sciences as their choice of study.

\section{The Elements of A New Flow Map based on aspects of Nature of Science (NOS)}

Despite continuing disagreements about a specific definition for NOS, at a certain level of generality and within a certain period of time, there is a "shared wisdom" about NOS. By considering issues related to accessibility for students, recognition by the public and usefulness for citizens, Lederman (2007) has proposed the following:

Scientific knowledge is tentative (subject to change), empirically based (based on and/or derived from observations of the natural world), and subjective (involves the personal background, biases, and/or is theory-laden); necessary involves human inference, imagination, and creativity (involves the invention of explanations); and is socially and cultural embedded. Two additional important aspects are the distinction between observation and inferences, and the functions of and relationships between theories and laws.

We insist that none of these aspects should be considered apart from the others. Thus, these key aspects of NOS should be viewed in this study as interdependent, dynamic, explicit and reflective. (See the right side in Fig. 1) Empiricists argue that our perception gives us objective facts about the world, configuring the foundations of science, and general laws and theories are inductively produced based on those facts. However, our perception is not objective. 'Judgments and inferences on observable facts' in a specific situation will change depending on the person, depending on the culture, and depending on the theoretical school.

That is, under the theme of 'social and cultural background,' perception is formed and developed in a decisive manner by the subjectivity of observers, their cultural and theoretical background, their expectations, and their perspectives. Such consideration is handled under the title 'the theory-ladenness of observation' in the philosophy of science. Also, they say that law, showing regularity, and theory, requiring our creativity, should be separated. We insist that law, showing regularity, and theory, requiring our creativity, should be dynamic rather than separate because of the theoryladenness of observation. Likewise, most modern philosophers of science have questioned the hierarchical/ dichotomous relationship between laws and theories (Giere, 1999; Nias \& Maza, 2011, p. 5). 
The development of scientific knowledge involves making observations of nature. That is, it is said that observations are not 'scientific methods' represented by induction.

Finally, because objective law or theory is not produced from objective facts, a scientific theory is, indeed, tentative.

\section{The Flow Map of NOS through the Pre- requisite of Kuhn's Scientific Revolution and the Key Aspects of NOS}

\section{The Crisis in normal science due to the number of serious anomalies}

The Social and Cultural Embeddedness of Scientific Knowledge and the Crisis of Kuhn's Normal Science. Science as a human enterprise is practiced in the context of a larger culture, and its practitioners are products of that culture. Science, it follows, affects and is affected by the various elements and intellectual spheres of the culture in which it is embedded (Lederman et al., 2002). Therefore, anomalies are also regarded as serious if they are important with respect to some pressing social need. Also bearing on the seriousness of an anomaly is the length of time that it resists attempts to remove it (Charmers, 1999, p. 113).

The seriousness of a Crisis, due to the appearance of an alternative.

Subjective: The Theory-Laden Nature of Scientific Knowledge and the seriousness of Kuhn's normal science crisis. Observations (and investigations) are always motivated and guided by questions or problems, and they acquire meaning in reference to these questions or problems, which are derived from certain theoretical perspectives (Lederman et al., 2002). According to Kuhn, a new paradigm, or a sufficient hint to permit later articulation of a new paradigm, emerges suddenly, sometimes in the middle of the night, in the mind of a man deeply immersed in crisis (Charmers, 1999, p. 114).
The Revolution Completion by disciplinary successors of a new paradigm

Through the continuous studies of disciplinary successors, additional empirical observations accumulate for resolving serious anomalies, and through these anomalies and the new observations and inferences that explain them, new laws and theories are generated.

Observations are descriptive statements about natural phenomena that are directly accessible to the senses (or extensions of the senses) and about which observers can reach consensus with relative ease. By contrast, inferences are statements about phenomena that are not directly accessible to the senses (Hull, 1998, p. 146).

Scientists derive specific testable predictions from theories and check them against tangible data. Closely related to the distinction between observation and inference is the distinction between scientific theories and laws. In general, laws are descriptive statements of relationships among observable phenomena. Theories and laws are different kinds of knowledge, and one does not become the other. However, we insist that law, showing regularity, and theory, requiring our creativity, should be dynamic rather than separate because of the theory-ladenness of observation. Also, Niaz \& Maza (2011) state as follows:

Researchers in current science education also questioned the dichotomy between theories and laws (McComas et al., 1998). Scientific progress is characterized by a series of theories or models (plausible explanations), which vary in the degree to which they explain/interpret/predict the experimental findings (Niaz \& Maza, 2011, p.5).

As shown in Fig. 1, in philosophy of Kuhn's philosophy that recognized the theory-ladenness of observation, their relationships between the empirical facts involving anomalies, inference, and scientific theories are dynamic, rather than the linear. Brown (1977) state as follows:

Only after Researcher has learned to see reality in 


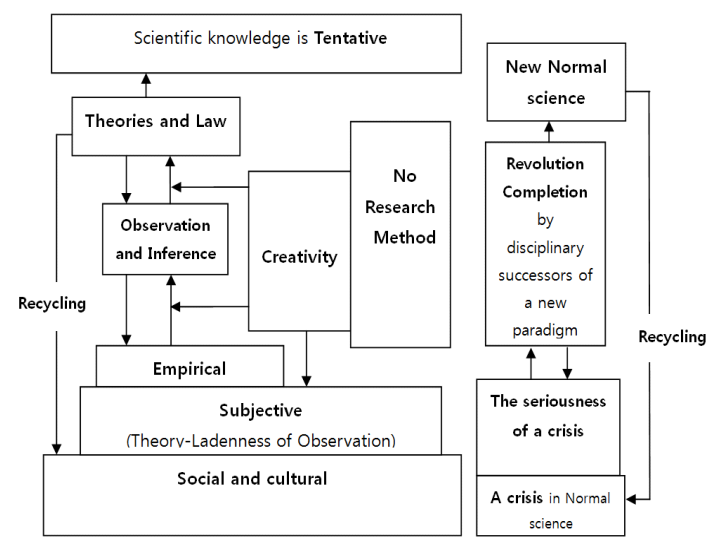

Fig. 1. Relationship between NOS and Kuhn's Scientific Revolution (Oh, 2012; Oh \& Lederman, 2014)

terms of acceptable theory is research possible, but it is also possible for the researcher to discover anomalies and thus come to reconsider acceptable theories. Theories often provide a definite description of what the scientist ought to see and thus sharpen his vision for the discovery of anomalies. And as long as the scientist is carrying on empirical investigation it is not theory alone which determines what will actually occur, but theory in conjunction with a theoryindependent world $\cdots$ It is the recalcitrant anomalies that eventually lead to the overthrow of one theory and its replacement by another $\cdots$ (Brown, 1977, pp. 108-109).

The development of scientific knowledge involves making observations of nature. Nonetheless, generating scientific knowledge also involves human imagination and creativity (Lederman, et al., 2002). Creativity is necessary with all inquiry procedures, based on all key aspects of NOS. One of the most widely held misconceptions about science is the existence of the scientific method. There is no single scientific method that guarantees the development of infallible knowledge (AAAS, 1993; NRC, 1996).

There are such things as Kuhn's scientific revolutions that involve a change, not just in the range of claims made but also in the kinds of entities (theories) that are assumed to make up the world and the kinds of evidence and modes of explanation that are deemed appropriate. Such changes come through a great deal of creativity on the part of disciplinary successors of a new paradigm.

\section{A new Normal Science stage and its Recycle (Expansion)}

After the completion of a scientific revolution through disciplinary successors, a new paradigm emerges. Scientific knowledge, although reliable and durable, is never absolute or certain. This knowledge, including facts, theories, and laws, is subject to change. Scientific claims change as new evidence, made possible through advances in thinking and technology, is brought to bear on these claims and as extant evidence is reinterpreted in the light of new theoretical advances, changes in cultural and social spheres, or shifts in the direction of established research programs. Tentativeness in science does not arise solely from the fact that scientific knowledge is inferential, creative, and socially and culturally embedded.

\section{New NOS Flow Map through Cognitive Strategy for the Nature of Science (NOS)}

\section{A cognitive learning outcome: Relations between NOS Flow Map Instruction Sequence and Conceptual Change Model}

Numerous educators striving to improve students' understanding of science have been designing activities to induce cognitive conflict, viewing it as an important component of learning and instruction (Niaz, 1995; Pearsall et al., 1997; Tsai \& Chang, 2005; Oh, 2011).

One of the most influential articles in conceptual change research is by Posner and Colleague. It is explicitly based on Kuhn's analysis of paradigm change in science (Posner et al., 1982). They proposed that, for individual conceptual change or learning to take place, four conditions must be met:

1. There must be dissatisfaction with current conceptions. 


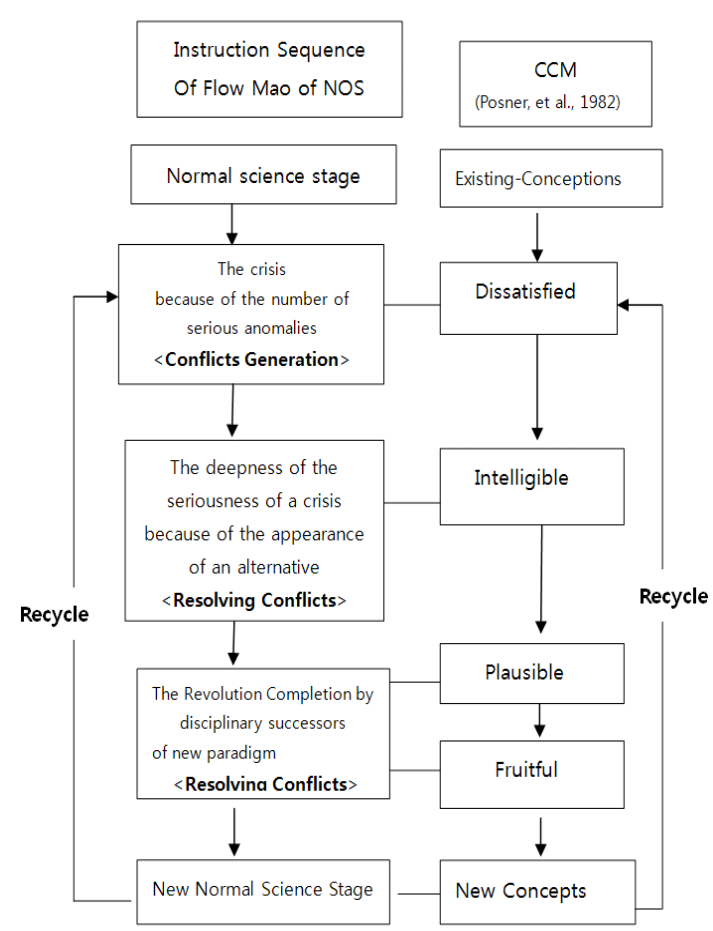

Fig. 2. Relations between NOS Flow Map Instruction Sequence and Conceptual Change Model

2. The proposed replacement conception must be intelligible.

3. The new conception must be initially plausible.

4. The new conception must suggest the possibility of a fruitful research program.

Fig. 2 indicates the NOS Flow Map, conditions of conceptual change of Posner et al. (1982). This flowchart is the criterion taxonomy of types of cognitive outcomes that students achieve after undergoing our suggested teaching and learning program. Students' conflicts toward discrepant events should be generated, in this study, these discrepant events are considered as the number of serious anomalies, and then continuously students should have understanding about the main principles of the scientific concepts that will be studied to resolve suggested discrepant events.

\section{A Conflict Map based on the Flow Maps of NOS}

Fig. 1 shows an example of using the Flow Map of NOS and a complete model of the instruction sequence toward top from bottom based on enhanced Conflict map as shown in Fig. 3. We use a Student Alternative Conception as previous paradigm, Naïve Scientific Concept as newly proposed paradigm, and Target Scientific Concept as accepted paradigm.

The conflict map proposed herein specifically asserts that students should resolve two conflicts during the process of conceptual change: one exists between new perception and students' alternative conception (conflict 1), and the other one exists between student alternative conception and the scientific one (conflict 2) (Hashweh, 1986). The resolution of conflict 1 does not necessarily clarify conflict 2 . Conflict 1 may be resolved through discrepant events, and resolution of conflict 2 could be achieved using "critical events or explanations" and relevant perceptions and conceptions that explicate the scientific conception (Tsai \& Chang, 2005).

Science educators and teachers could use these frameworks to draw NOS flow map of overcoming students' other alternative conceptions and then use them to conduct science instruction. The suggested instruction sequence could be Socially and cultural first and then subjective, and finally tentative, shown as Fig. 1.

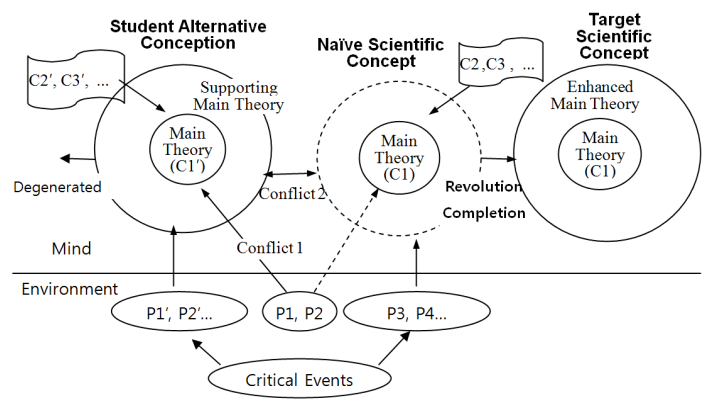

Note: P1', P2'...: perceptions supporting a main theory of Alternative conception

P1, P2: perceptions including a discrepant event

P3, P4, $\cdots$ : other perceptions supporting Naïve scientific concept $\mathrm{C} 1 \cdots$ : the Hard Core of Students' Existing Conception $\mathrm{Cl}{ }^{\prime} \cdots$ : the Hard core of Naïve Scientific Concept C2', C3'...: relevant scientific concepts supporting Alternative conception $\mathrm{C} 2, \mathrm{C} 3, \cdots$ : relevant scientific concepts supporting Naïve scientific concept

Fig. 3. A typical Conflict Map (Modified from Oh, 2011) 
According to Kuhn, an analysis of the characteristics of a crisis period in science demands the competence of the psychologist as much as that of historian (Chalmers, 1999, p.113).

The research literature about student misconceptions or alternative conceptions frequently cites the 'conceptual change model' proposed Conflict Map suggested by Tsai and Chang (2005), and Oh (2011), based on Posner et al. (1982) and Strike and Posner (1982), They, psychologists, assert that the following conditions are necessary for students to restructure their alternative conceptions during the process of conceptual change.

\section{$\langle$ Cognitive conflicts〉}

1. The crisis because of the number of serious anomalies: There must be dissatisfaction with existing conception 〈Flow Map〉

Suggesting discrepant events (P1, P2) between alternative conception $\left(\mathrm{Cl}^{\prime}\right)$ and new abnormal perceptions 〈Conflict Map: conflict 1〉

\section{〈Cognitive conflict Resolution〉}

2. The deepness of the seriousness of a crisis because of the appearance of an alternative: A new concept must be intelligible. 〈Flow Map〉 Suggesting the main theory of naïve scientific concepts 〈Conflict map: conflict 1 resolution〉 and then critical events between alternative conception and naïve scientific concept 〈Conflict Map: conflict 2 resolution〉

3. A new concept must appear initially plausible. The Revolution beginning by disciplinary successors of new paradigm〈Flow Map〉

Relevant Concepts with main theory of naïve scientific concept $\langle$ Conflict Map: Other supporting concepts $(\mathrm{C} 2, \mathrm{C} 3 \ldots)\rangle$

4. The Revolution Completion by disciplinary successors of new paradigm :

A new concept should be fruitful or open to new areas of inquiry. 〈Flow Map〉
The Refined works of naïve scientific concept $\langle$ Conflict Map: Other supporting perceptions (P3, P4...) $\rangle$

5. New concepts are accepted. New Normal Science stage〈Flow Map〉

Reflecting the results of scientific conceptual change/shift 〈Conflict Map: Can new scientific concepts explain the perceptions that symbolized students' alternative conceptions completely, partly, or not at all?

The use of NOS Flow Maps could make the status of conceptual change more explicit for teachers and students, because of the high consistency between the Conceptual Change Model and the ideas of NOS Flow Maps through a enhanced Conflict Map which is suggested as a sequence of instruction.

According to Matthews (2002), one of the most influential articles in conceptual change research is by George Posner and colleagues "Accommodation of a Scientific Conception: Toward a Theory of Conceptual Change". It is explicitly based on Kuhn's analysis of paradigm change in science (Posner et al., 1982).

\section{Historical Case Studies and a cognitive learning outcome}

\section{Historical Case Studies: The Flow Map of NOS for the process of the establishment of Copernicus's Heliocentric Hypothesis}

Since Kuhn had examined this episode in detail in his earlier book on the Copernican revolution (Kuhn, 1962, pp. 139-140), he could presumably use it with strong confidence in supporting Kuhn's theory of revolutions.

\section{$\langle$ Cognitive conflicts〉}

The Crisis in normal science due to the number of serious anomalies

Socio-cultural pressure

The crisis of Ptolemy's geocentric system: For 
some time, astronomers had every reason to suppose that these attempts would be as successful as those that had led to Ptolemy's system. Astronomers were invariably able to eliminate a given discrepancy by making an adjustment in Ptolemy's system of compounded circles.

As time went on, a man looking at the net result of many astronomers' research could observe that the complexity was increasing far more rapidly than the accuracy. 〈Suggesting discrepant events between alternative conception $\left(\mathrm{Cl}^{\prime}\right)$ and new abnormal perceptions, Conflict Map: conflict 1>

\section{$\langle$ Cognitive conflict Resolution〉}

The seriousness of a Crisis, due to the appearance of an alternative

The appearance of Copernicus's system, an alternative for Ptolemy's system: After repeatedly examining old data and after lengthy contemplation, Copernicus concluded that placing the Sun in the center of the universe would allow for a simpler depiction of planetary motion. Upon consideration, where else would be a better place for the Sun that illuminates the universe than the universe's center? (Vigoureux, 2003, p. 86). 〈Conflict Map: conflict 1 resolution〉

Galileo's Critical Event “The phases of Venus offered positive support for the heliocentric system. In the geocentric system, Venus is always more or less between the Sun and the Earth and must always appear as a crescent. In the heliocentric system, Venus travels behind the Sun and can appear nearly fullwhich the telescope reveals" (Westfall, 1971, p.13). Galileo thought that this change of appearance occurred because Venus orbited around the Sun. This change is possible only when Earth and Venus orbit around the Sun. Ultimately, the changing phases of Venus supported Copernicus. 〈Conflict Map: conflict 2 resolution〉

Revolution Completion by disciplinary successors of a new paradigm

The two rival systems were more or less on a par as far as simplicity and accord with observations of planetary positions are concerned. Nevertheless, a number of mathematically capable natural philosophers
(Galileo, Kepler, and Newton) were attracted to the Copernican system. With Kepler, the Copernican revolution was nearly 'complete'; Kuhn finds its final completion in Newton's system (Sharrock, \& Read, 2002, p. 79). Bringing together mathematicians and natural philosophers was a fundamental shift, one that involved social changes as well as intellectual ones. Over a hundred years went by before Newton fused their two approaches together in his book on gravity, making astronomy a mathematical science that aimed both to describe and to explain the cosmos.

"Opposition to Copernicanism did not simply collapse, but persisted, and only gradually faded away over the 150 years after the dearth of Galileo in 1642" (Sharrock \& Read, 2002, p. 80). "The main attraction of the Copernican hypothesis was in how clearly it explained a number of features of planetary motion, which could be explained by the rival Ptolemaic theory only in an unattractive, artificial way. 〈Conflict Map: Other supporting concepts $>$

The completion of Kepler, and Bessel's obtaining a star's parallax

“It was Galileo's contemporary, Kepler, who contributed a major breakthrough in that direction when he discovered that each planetary orbit could be represented by a single ellipse, with the sun at one focus. This eliminated the complex system of epicycles that both Copernicus and Ptolemy had found necessary" (Charmers, 1999, p.100). Although the parallax-distance relation is mathematically a very simple formula, obtaining a star's parallax to use in the formula is very difficult because the angle by which the star shifts is extremely small. It was not until the 1980 s that the first parallax was measured by German astronomer Friedrich Bessel at Königsberg Observatory (now in Kaliningrad). 〈Conflict Map: Other supporting perceptions >

New Normal science stage and its Recycle; the Expansion of Normal Science

"Galileo and Kepler certainly strengthened the case in favor of the Copernican theory. However, more developments were necessary before that theory was securely based on a comprehensive physics. Newton 
was able to take advantage of the work of Galileo, Kepler and others to construct that comprehensive physics. Once Newton's physics had been constituted, it was possible to apply it in detail to astronomy, fluid mechanisms and other domains." (Chalmers, 1982, p. 74).

\section{New Normal Science: Updating}

Continuously expansive Newtonian models were applied to fluid mechanisms and other domains. Astronomers have long known that the major axis of Mercury's orbit does not remain fixed in space in relation to the stars. The major axis rotates around in the plane of the orbit. Part of this shifting arises from the gravitational attraction of the other planets. When this and other effects are taken into account, there nonetheless remains a residual shift of 41 arcsec per century.

Is it perhaps an undiscovered planet, sometimes called Vulcan, orbiting within Mercury's orbit? (Newtonian model's auxiliary hypotheses). No such planet has ever been definitively observed (observation unexpected by Newton theory).

〈Conflict Map: Can new scientific concepts explain the perceptions that symbolized students' alternative

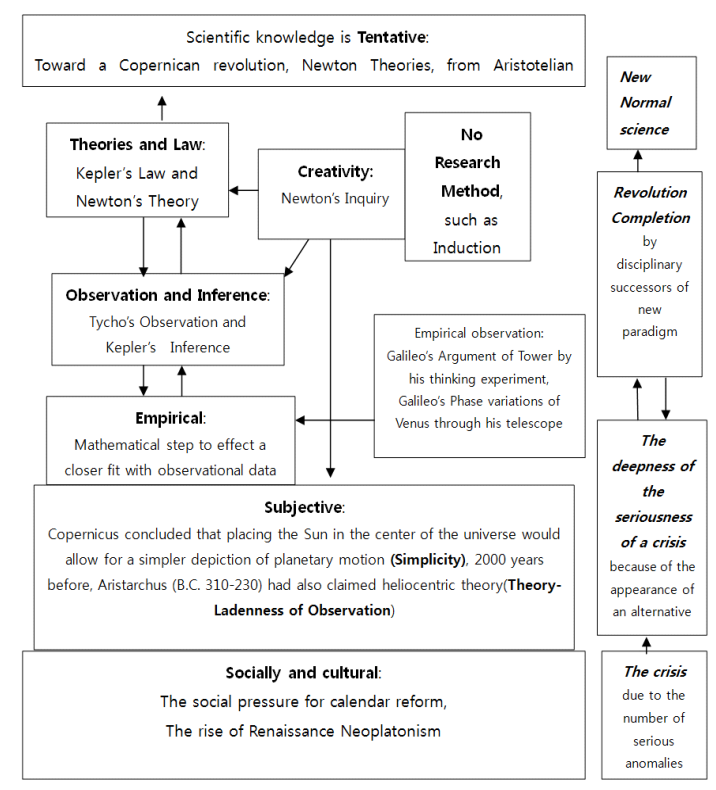

Fig. 4. The Copernican revolution: the Flow Map of the Nature of Science (NOS) conceptions completely, partly, or not at all? $>$

Recycle: retreating or revising Newton's theory

Astronomers have long known that the major axis of Mercury's orbit does not remain fixed in space in relation to the stars. General relativity predicts a motion influenced by the strong curvature of space-time close to the sun. Because the observed and predicted results coincide to within a few percentage points, observations confirm general relativity.

\section{Preservice Eementary Teachers' views about using NOS Flow Map through a Conflict Map}

Many researches emphasize that explicitness and reflectivness should aimed at developing teachers' concepts of NOS through a Conflict Map. Because "despite the relative 'effectiveness' of the explicit approach, much is still required in terms of fostering among science teachers 'desired' understandings of NOS” (Abd-El-Khalick, \& Lederman, 2000a, p.665; Akerson \& Abd-El-Khalick, 2003). Through Recent research (Akerson et al., 2006), it was found that most preservice elementary teachers held inadequate ideas of nature of science prior to instruction.

Using this NOS Flow Map throgh a Conflict Map in a way in which preservice elementary teachers could explicit reflective NOS instruction in elementary classrooms would help improve their awareness of the importance of their retention of these ideas for their future teaching settings. Thus, at first it should be established preservice elementary teachers' views about use of NOS Flow Maps through a Conflict Map.

Participants and Methods: 78 preservice elementary teachers completed a questionnaire. The preservice elementary teachers were enrolled on courses in a Literacy Program in J. National University of Education of South Korea. Before answering the questionnaire, all of these pre-service elementary teachers had been instructed to the theory of constructivism. The questionnaire employed a 5-1 Likert scale and the administration of the questionnaire was anonymous, 
and modified questionnaire which was developed In order to establish teachers' views about use of Tsai's conflict maps (Tsai, 2000). A male science professor with twenty years of teaching experience, who was assisted by a male science teaching assistant with ten years of teaching experience in K.-S. girls' high school, taught all classes. The professor held a Bachelor of Science degree and a Master of Science degree in astronomy, as well as a doctoral degree in science education.

Results and Discussion: The results of the questionnaire are presented in Table 1. Most of the surveyed preservice liked the idea of using NOS Flow maps (item 1) and also agreed that the process of developing NOS Flow maps through a Conflict Map helped them design better instructional plans about the NOS key (items 2,3). Many of them believed in cognitive learning of using NOS Flow maps in science instruction (items 9). The effectiveness of using NOS Flow maps was also well perceived by most of them (items 4). They also presumed that current preservice elementary teachers would like the idea of using NOS Flow maps. Many of these pre- service teachers, nevertheless, reflected that the construction of NOS Flow maps through a Conflict Map was not an easy process (item 5). Therefore, it is recommended that teachers cooperate with one another to develop appropriate NOS Flow maps for students and teachers See Table 1.

\section{Discussion and Conclusion}

The NOS aspects have been emphasized in recent science education reform documents as disagreeing with the received views of common science (AAAS, 1993; NRC, 1996). Scientific knowledge is tentative; empirical; theory-laden; the product of human inference, imagination, and creativity; and socially and culturally embedded. Three additional important aspects are the distinction between observation and inference, the lack of a universal method for doing science, and the functions of and relationships between science theories and laws.

First, we suggest the use of flow maps through a Conflict Map for teaching the key aspects of the nature of science, as the Historical Case of Science Studies.

Table 1. Preservice Elementary Teachers' Views About Using NOS Flow Maps

\begin{tabular}{|c|c|c|c|c|c|c|}
\hline Question & $\begin{array}{l}\text { Strongly } \\
\text { agree } \\
\mathrm{N}(\%)\end{array}$ & $\begin{array}{l}\text { Agree } \\
\mathrm{N}(\%)\end{array}$ & $\begin{array}{c}\text { Neutral } \\
\mathrm{N}(\%)\end{array}$ & $\begin{array}{l}\text { Disagree } \\
\mathrm{N}(\%)\end{array}$ & $\begin{array}{l}\text { Strongly } \\
\text { disagree } \\
\mathrm{N}(\%)\end{array}$ & $\begin{array}{l}\text { Sum } \\
\mathrm{N}(\%)\end{array}$ \\
\hline 1. I like the idea of using a NOS flow map throgh a Conflict Map. & $15(19)$ & $52(67)$ & $9(12)$ & $2(2)$ & & $78(100)$ \\
\hline $\begin{array}{l}\text { 2. The process of constructing a NOS flow map furthers my under- } \\
\text { standing of NOS aspects throgh a Conflict Map. }\end{array}$ & $13(17)$ & $51(65)$ & $13(17)$ & $1(1)$ & & $78(100)$ \\
\hline $\begin{array}{l}\text { 3. The process of using a NOS flow map gives me a more integrated } \\
\text { both Implicit and explicit attempts about the NOS key aspects throgh } \\
\text { a Conflict Map that will be taught. }\end{array}$ & $16(20)$ & $52(67)$ & $10(13)$ & & & $78(100)$ \\
\hline $\begin{array}{l}\text { 4. Compared to traditional teaching methods, the use of a NOS flow } \\
\text { map throgh a Conflict Map is expected to achieve better learning } \\
\text { outcomes for students. }\end{array}$ & $17(22)$ & $50(64)$ & $9(12)$ & $2(2)$ & & $78(100)$ \\
\hline $\begin{array}{l}\text { 5. The construction of a NOS flow map throgh a Conflict Map is an } \\
\text { easy process. }\end{array}$ & $3(4)$ & $14(18)$ & $31(40)$ & $27(34)$ & $3(4)$ & $78(100)$ \\
\hline 6. I am eager to view other teachers' NOS flow map throgh a Conflict Map. & $9(12)$ & $51(65)$ & $17(22)$ & $1(1)$ & & $78(100)$ \\
\hline $\begin{array}{l}\text { 7. I am eager to explore whether a NOS flow map throgh a Conflict } \\
\text { Map is useful for the students and teachers. }\end{array}$ & $23(30)$ & $43(55)$ & $12(15)$ & & & $78(100)$ \\
\hline $\begin{array}{l}\text { 8. In order to construct a NOS flow map throgh a Conflict Map, I have } \\
\text { read some other relevant literature. }\end{array}$ & $11(14)$ & $47(61)$ & $19(24)$ & 1( 1$)$ & & $78(100)$ \\
\hline $\begin{array}{l}\text { 9. I believe the use of a NOS flow map throgh a Conflict Map could } \\
\text { be applied to cognitive learning of science instruction. }\end{array}$ & $16(21)$ & $44(56)$ & $18(23)$ & & & $78(100)$ \\
\hline
\end{tabular}


Second, our flow maps include NOS, HOS, SCK, and POS, with their instructional sequence suggested from bottom to top. We present a strategy that begins with the most important core aspects of NOS and then introduces supportive SCK and HOS to explain the cores as cognitive learning outcomes through a Conflict Map. These concepts are presented explicitly and reflectively, providing a means for teachers to help students reconstruct alternative concepts based on new scientific knowledge. However, preservice elementary teachers responded that, although it is necessary to employ such strategies, it is actually difficult to develop such a sequence. Therefore, it is necessary to develop NOS Flow Maps through a Conflict Map, and strategies that are easy to follow and are widely applicable.

Third, the development of Flow Maps for the key aspects of the nature of science is good cases to Copernicus Revolution, the main accidents of the history of Astronomical Science, as the Historical Case Studies.

The knowledge of HPS should be taught in our science teachers' programs. Some knowledge of HPS for the nature of science can be as useful to students as to working scientists. Even though this study did not demonstrate that HOS played a dual role in significantly increasing student scores for both NOS and SCK, it is apparent that HOS provides instructional resources for science teaching if HOS is explicitly contextualized into domain-specific content. A teacher of science must also bring to the classroom the attitude and world view of scientists because experiencing the processes of science alone is not sufficient. To achieve this, a basic understanding of Kuhn's philosophy of science is necessary.

There is a main limitation to the present investigation. Learning and teaching outcomes related to scientific inquiry and teaching of a flow map of NOS through a Conflict Map were not presented in a pre-service teachers and students. Formal assessment of the effects of a Flow map of NOS through a Conflict Map toward these learning outcomes will be needed at our future research.

\section{References}

Abd-El-Khalick, F. (2006). Over and over again: college students' views of nature of science, In L.B. Flick and N.G. Lederman (Eds.), Scientific Inquiry and Nature of Science (pp. 389-425). The Netherlands: Springer.

Abd-El-Khalick, F. \& Lederman, N. G. (2000a). Improving science teachers' conceptions of the nature of science: A critical review of the literature. International Journal of Science Education, 22(7), 665-701.

Abd-El-Kalick, F. \& Lederman, N. G. (2000b). The influence of history of science courses on students' views of nature of science. Journal of Research in Science Teaching, 37(10), 1057-1095.

Akerson, V. L. \& Abd-El-Khalick, F. S. (2003). Teaching elements of nature of science: Yea long case study of a fourth grade teacher. Journal of Research in Science Teaching, 40, 1025-1049.

Abd-El-Khalick, F. \& BouJaoude, S. (1997). An exploratory study of the knowledge base for science teaching. Journal of Research in Science Teaching, 34(7), 673699.

Akerson, V. L., Morrison, J. A. \& McDuffie, A. R. (2006). One course is not enough: Preservice elementary teachers' retention of improved views of nature of science. Journal of Research in Science Teaching, 43(2), 194-213.

American Association for the Advancement of Science. (AAAS) (1993). Benchmarks for science literacy: A Project 2061 report. New York: Oxford University Press.

Bartholomew, H., Osborne, J. \& Ratcliffe, M. (2004). Teaching students "ideas-about-science": Five dimensions of effective practice. Science Education, 88, 655-682.

Benson, G. D. (1989). Epistemology and science curriculum. Journal of Curriculum Studies, 21(4), 329-344.

Brown, H. I. (1977). Perception, theory and commitment: The new philosophy of science. Chicago: The University of Chicago Press.

Buaraphan, K. (2012). Embedding nature of science in teaching about astronomy and space. Journal of Science Education and Technology, 21, 353-369.

Cleminson, A. (1990). Establishing an epistemological base for science teaching in the light of contempory notions of the nature of science and how children learn science. Journal of Research in Science Teaching, 27(5), 429-445.

Chalmers, A. F. (1982). What is this thing called science? 
(2nd edition). Miton Keynes: Open University Press.

Chalmers, A. F. (1999). What is this thing called science? (3rd edition). Cambridge: Hackett Publishing, Inc.

Dass, P. M. (2005). Understanding the nature of scientific enterprise (NOSE) through a discourse with its history: the influence of an undergraduate 'history of science' course. International Journal of Science and Mathematics Education, 3(1), 87-115.

Duschl, R. A. (1990). Restructuring science education: The importance of theories and their development. New York: Teachers college press.

Eflin, J. T., Glennan, S. \& Reisch, G. (1999). The nature of science: A perspective from the philosophy of science. Journal of Research in Science Teaching, 36(1), 107-116.

Giere, R. N. (1999). Science without laws. Chicago: University of Chicago Press.

Hashweh, M. Z. (1986). Toward an explanation of conceptual change. European Journal of Science Education, 8, 229-249.

Hull, D. L. (1998). Science as a process: an evolutionary account of the social and conceptual development of science. Chicago: University of Chicago Press.

Irwin, A. R. (2000). Historical case studies: Teaching the nature of science in context. Science Education, 84(1), $5-26$.

Jenkins, E. W. (1994). HPS and school science education: remediation or reconstruction? International Journal of Science Education, 16(6), 613-623.

Kuhn, T. S. (1959). The essential tension: Traditional and innovation in scientific research. The third University of Utah Research Conference on the Identification of Scientific Talent, University of Utah Press, Salt Lake City, Reprinted in his The Essential Tension, Chicago: University of Chicago Press, pp.225-239.

Kuhn, T. S. (1962). The structure of scientific revolution (1st edition), Chicago, IL: The University of Chicago Press.

Kuhn, T. S. (1970). The structure of scientific revolution (2nd edition), Chicago, IL: The University of Chicago Press.

Kuhn, T. S. (1977). The essential tension. Chicago: University of Chicago Press.

Kuhn, T. S. (1996). The structure of scientific revolutions ( $3^{\text {rd }}$ Edition), Chicago: The University of Chicago Press.

Jenkins, E. W. (1994). HPS and school science education: remediation or reconstruction? International Journal of Science Education, 16(6), 613-623.
Lederman, N. G. (2007, reprint 2010 by Routledge). Nature of Science: Past, present, and future. In K. Abell \& N. G. Lederman (Eds.), Handbook of research on science education. Mahwah (pp.831-880), New Jersey: Lawrence Erlbaum Associates Publishers.

Lederman, N. G., Abd-El-Khalick, F., Bell, R. L. \& Schwartz, R. S. (2002). Views of NOS questionnaire toward valid and meaningful assessment of learners' conceptions of NOS. Journal of Research in Science Teaching, 39, 497-521.

Lin, H. \& Chen, C. (2002). Promoting preservice chemistry teachers' understanding about the nature of science through history. Journal of Research in Science Teaching, 39(9), 773-792.

Matthews, M. (1992). History, philosophy, and science teaching: The present rapprochement, Science \& Education, 1, 11-47.

Matthews, M. (1994). Science teaching: The role of history and philosophy of science. New York: Rutledge.

Matthews, M. (2002). Thomas Kuhn's impact on science education: What lessons can be learned? Science Education, 88, 90-118.

Matthews, M. (2004). Thomas Kuhn's impact on science education: What lessons can be learned? Science Education, 88(3), 90-118.

Monk, M. \& Osborne, J. (1997). Placing the history and philosophy of science on the curriculum: A model for the development for pedagogy. Science Education, 81(4), 405-424.

National Research Council (NRC) (1996). National science education standards. Washington. DC: National Academic Press.

Niaz, M. (1995). Cognitive conflict as a teaching strategy in solving chemistry problems: A dialectic-contstructivist perspective. Journal of Research in Science Teaching, 32, 959-970.

Niaz, M. \& Maza, A. (2011). Nature of science in general chemistry textbooks. New York: Springer.

Oh, J.-Y. \& Lederman, N. G. (2014). Suggesting an explicit flow map for the nature of science. 2014 Kase International Conference (p.143), at Daegu Unversity, Korea, Feb.13-15, 2014.

Oh, J.-Y. (2012). Suggesting a flow map of the nature of science for sciences education, The paper presented in the International Conference of the ICSE 2012 conference in Nanjing, China (Oct. 12-15, 2012).

Oh, J.-Y. (2011). Using an enhanced conflict map in the classroom (photoelectric effect) based on Lakatosian 
Heuristic Principle Strategies. International Journal of Science and Mathematics Education, 9, 1135-1166.

Pearsall, N. R., Skipper, J. E. \& Mintzes, J. J. (1997).

Knowledge restructuring in the life sciences: A longitudinal study of conceptual change in biology. Science Education, 81, 193-215.

Posner, G., Strike, K. A., Hewson, P. W. \& Gertzog, W. A. (1982). Accommodation of a scientific conception: Toward a theory of conceptual change. Science Education, 66(2), 211-277.

Schwartz, R. S., Lederman, N. G. \& Crawford, B. A. (2004). Developing views of nature of science in an authentic context: An explicit approach to bridging the gap between nature of science and scientific inquiry. Science Education, 88, 610-645.

Schwartz, R. \& Lederman, N. (2002). It's the nature of the beast: The influence of knowledge and intentions on learning and teaching nature of science. Journal of Research in Science Teaching, 39(3), 205-236.

Sharrock, W. \& Read, R. (2002). KUHN: Philosopher of scientific revolution. Malden. MA: Polity Press c/o Blackwell Publishing Ltd.

Solomon, J., Duveen, J., Scott, L. and McCarthy, S. (1992). Teaching about the nature of science through history: Action research in the classroom. Journal of Research in Science Teaching, 29(4), 409-421.

Tsai, C.-C. (2000). Enhancing science instruction: the use of 'conflict map'. International Journal of Science Education, 22(3), 285-302.

Tsai, C.-C. \& Chang, C.-Y. (2005). Lasting effects of instruction guided by the conflict map: Experimental study of learning about the causes of the seasons. Journal of Research in Science Teaching, 42(10), 10891111.

Vigoureux, J. M. (2003). Les pommes de Newton. Paris: Albin Michel S.A., (Trans. Hee-Jung Lee, (2005), Newton's Apple, NuRim book(Seoul)).

Westfall, R. S. (1971). The construction of modern science. New York: John Willey \& Sons, Inc. 